\title{
Effect of $\alpha$-tocopherol supplementation in diluents on the motility, viability and plasma membrane integrity of Simmental bull spermatozoa after cooling
}

\section{Pengaruh suplementasi $\alpha$-tocopherol dalam diluen terhadap motilitas, viabilitas dan integritas plasma membran spermatozoa sapi Simmental setelah pendinginan}

\author{
Sarah Azura ${ }^{1 *}$, Hermin Ratnani ${ }^{2}$, Koesnoto Soepranianondo ${ }^{3}$,Suherni Susilowati ${ }^{2}$, \\ Mas'ud Hariadi $^{2}$, Abdul Samik ${ }^{2}$ \\ ${ }^{1}$ Student, ${ }^{2}$ Department of Veterinary Reproduction, ${ }^{3}$ Department of Animal Husbandry \\ Faculty of Veterinary Medicine Universitas Airlangga \\ Corresponding author, e-mail: sarahazura96@gmail.com
}

\begin{abstract}
Semen storage in cold temperatures might cause an increase in reactive oxygen species (ROS) production. This condition resulted in spermatozoa damage and quality decrease. This study was conducted to investigate the effects of $\alpha$-tocopherol supplementation in diluents on the motility, viability, and plasma membrane integrity of Simmental bull spermatozoa after cooling. Semen samples were diluted in skim milk egg yolk supplemented with $0,0.5,1.0$, and $1.5 \mathrm{mM} \alpha$-tocopherol respectively for control, T1, T2, and T3. Spermatozoa were evaluated for their motility, viability, and membrane integrity in cooling temperature $\left(5^{\circ} \mathrm{C}\right)$. The daily evaluation showed that $1.5 \mathrm{mM} \alpha$-tocopherol was the best in maintaining motility, viability, and plasma membrane integrity, while $1.0 \mathrm{mM} \alpha$-tocopherol was only good for maintaining viability. Therefore, it can be concluded that $\alpha$-tocopherol at the concentration of $1.5 \mathrm{mM}$ was an efficient antioxidant supplement for Simmental cattle semen in skim milk egg yolk diluent.
\end{abstract}

Keywords: Simmental, $\alpha$-tocopherol, motility, viability, plasma membrane integrity

\section{INTRODUCTION}

Simmental is one of the beef cattle breeds included in the Bos taurus. There are many Bos taurus cattle such as Simmental, Limousine, and Angus. The Simmental has a very high level of body weight gain (Soeharsono et al., 2010) an important role in fulfilling the need of meats in society, the demand weight up to $650-660 \mathrm{~kg}$, and a rapid grow. Based on the above considerations, it is necessary to preserve and accelerate the increase in Simmental cattle population. An effort to accelerate the increase of Simmental cattle population can be done through the use of artificial insemination (AI) technology. The quality of semen has a great impact on the success of AI practice, which includes dilution and storage of semen.

Semen diluter has several requirements, such as providing food substances as an energy source of spermatozoa, ability to prevent cold shock, containing substances that can stop or inhibit the activity of bacteria found in semen, act as a buffer to prevent changes in $\mathrm{pH}$ and includes maintaining the balance of osmotic pressure and electrolytes (Bebas et al., 2016). Semen dilution is an attempt to increase the volume of semen, reduce the density of spermatozoa and maintain the survival of spermatozoa in a certain storage time limit in conditions below or above freezing temperature (Kusumaningrum et al., 2002). The damage of spermatozoa cells caused by cold shock can also be minimized by the addition of antioxidants. Spermatozoa damage may be caused by many things, some of which were age factors, infection of the testicular organs, lack of protamine levels, hormonal, toxic chemicals contamination, drugs, hyperthermia of the testes, apoptosis, and especially high level of reactive oxygen species (ROS) (Priyanto et al., 2015). ROS also could reduce spermatozoa motility through peroxidation of spermatozoa cell membranes, which induced a decrease in 
flexibility and movement of spermatozoa tails (Tremellen, 2008).

The body itself could limit the damage caused by free radicals by equipping a set of defence systems to counteract attack of free radicals or oxidants (Singh, 1992; Jackson, 2005). The defences systems were antioxidant like micronutrients such as $\beta$-carotene, vitamin C, and vitamin E (Hariyatmi, 2004). However, in certain circumstances, when the production of free radicals or reactive oxygen compounds exceeded the body's defensive ability, oxidative stress occurred (Agarwal et al., 2003). One of the vitamins that are a fat-soluble antioxidant, able to captivate free radicals, and prevent chain reactions is Vitamin E ( $\alpha$-tocopherol) (Suryohudoyo, 1995). Based on the background above, research examining the effect of the addition of $\alpha$-tocopherol to diluter on motility, viability, and plasma membrane integrity of Simmental cattle spermatozoa in cooling temperature was conducted.

\section{MATERIALS AND METHODS}

\section{Semen collection and evaluation}

A Simmental cattle used in this study was 4-5 years old, showing high libido and healthy reproductive organs. Five ejaculates were collected using an artificial vagina and teaser bull twice a week. The collected semen was immediately evaluated macroscopically (volume, $\mathrm{pH}$, viscosity, colour, and odour), and microscopically (motility, and viability).

Each ejaculate was aliquoted into four tubes, which were subjected to be mixed (1:10) with skim milk egg yolk diluent supplemented with four different concentrations of $\alpha$-tocopherol (C29H50O2, Tokyo Chemical Industry). The $\alpha$-tocopherol concentrations were $0,0.5,1.0$, and $1.5 \mathrm{mM}$, respectively for control/T0, T1, T2, and T3 groups.

\section{Treatment of semen sample}

The semen samples were then cooled at $5{ }^{\circ} \mathrm{C}$ and observed for their motility, viability, plasma membrane integrity just before cooling (0 hours), and then every 24 hours until the motility was less than or equal to $40 \%$.

\section{Evaluation of spermatozoa motility}

The progressive movement of spermatozoa was evaluated using a $1: 1$ mixture of semen and $0.9 \%$ saline on an object glass. The observation was conducted using a phasecontrast microscope with a magnification of $400 \times$ (Susilowati et al., 2010).

\section{Evaluation of spermatozoa viability}

Spermatozoa viability was evaluated utilizing eosin nigrosin staining. One drop of semen and one drop of eosin nigrosin were homogenously mixed on a clean object glass, smeared and fixed by quickly passing through the flame of a Bunsen burner several times. The fixed sample was observed using a phasecontrast microscope under 400x magnification. Dead spermatozoa are stained because of the loss of the lipoid layer, whereas viable spermatozoa were unstained because of the intact lipoid layer on the cell surface, which protected the spermatozoa. Therefore, the dead spermatozoa appear red or purple, whereas the viable spermatozoa remain uncoloured (Susilowati et al., 2010).

\section{Spermatozoa plasma membrane integrity}

Plasma membrane integrity was evaluated using the hypoosmotic swelling (HOS) test. One hundred $\mu \mathrm{l}$ of semen was diluted ten times in hypoosmotic solution (0.735 $\mathrm{gr}$ Sodium citrate, $1.351 \mathrm{gr}$ fructose, and $100 \mathrm{ml}$ distilled water) and incubated in a $\mathrm{CO}_{2}$ incubator at $37{ }^{\circ} \mathrm{C}$ for one hour. After incubation sample was mixed with eosin nigrosin and smeared on an object glass. The observation was performed using a phasecontrast microscope under $400 \mathrm{x}$ magnifications. In this test, spermatozoa with intact plasma membrane appeared swollen at some different part of the tail or coiled at the caudal part of the tail (Susilowati, et al., 2010).

\section{RESULTS}

Macroscopic examination of five semen ejaculates showed an average volume of $7.9 \mathrm{ml}$, $\mathrm{pH}$ 6.6, viscous, creamy white coloured, and smell similar to cow's milk; meanwhile, microscopic examination showed the average 
mass movement of $+2 /+3$; progressive individual movements of $82 \%$; the individual velocity of 3 ; concentration of $1,324 \times 10^{6}$ spermatozoa. $\mathrm{mL}^{-1}$; viability of $92.8 \%$ and plasma membrane integrity of $63.6 \%$.

After the feasibility test, each ejaculate was aliquoted for four treatment groups with the supplementation of $0,0.5,1.0$, and $1.5 \mathrm{mM} \alpha-$ $\alpha$-tocopherol in skim milk egg yolk diluent cooled at $5{ }^{\circ} \mathrm{C}$. First observations were performed immediately after mixing with the diluent just before cooling and after that daily until 72 hours after cooling, where spermatozoa motility in most of the groups was less than $40 \%$.

Motility evaluation shows that the fastest decrease in motility was found in the T0 group, while the slightest decrease in motility was found in the T3 group (Table 1.1). A significant difference $(\mathrm{p}<0.05)$ in motility was already seen 24 hours after cooling. Significant differences continued until 72 hours after cooling.

Table 1 Spermatozoa motility (\%, means \pm SD) after cooling in skim milk egg yolk diluent with $\alpha$ tocopherol supplementation

\begin{tabular}{lcccc}
\hline & \multicolumn{4}{c}{ time of observation after cooling (hours) } \\
\cline { 2 - 5 } & 0 & 24 & 48 & 72 \\
\hline T0 & $81.4 \pm 3.7^{\mathrm{a}}$ & $59.8 \pm 3.4^{\mathrm{a}}$ & $42.4 \pm 7.9^{\mathrm{a}}$ & $24.6 \pm 2.6^{\mathrm{a}}$ \\
T1 & $82.8 \pm 2.2^{\mathrm{a}}$ & $64.6 \pm 4.3^{\mathrm{ab}}$ & $52.6 \pm 4.3^{\mathrm{b}}$ & $35.8 \pm 6.7^{\mathrm{b}}$ \\
T2 & $82.0 \pm 3.4^{\mathrm{a}}$ & $69.2 \pm 3.8^{\mathrm{bc}}$ & $55.0 \pm 6.5^{\mathrm{b}}$ & $39.2 \pm 4.4^{\mathrm{b}}$ \\
T3 & $81.8 \pm 2.0^{\mathrm{a}}$ & $73.4 \pm 6.4^{\mathrm{c}}$ & $65.6 \pm 7.1^{\mathrm{c}}$ & $56.6 \pm 4.7^{\mathrm{c}}$ \\
\hline
\end{tabular}

a, b, c different superscripts in the same column indicates significant difference ( $p<0.05)$; T0: control, without supplementation; T1: supplementation with $0.5 \mathrm{mM} \alpha$-tocopherol; T2: supplementation with $1.0 \mathrm{mM} \alpha$-tocopherol; T3: supplementation with $1.5 \mathrm{mM} \alpha$-tocopherol; replicates: 5 (ejaculates); cooling was conducted at $5{ }^{\circ} \mathrm{C}$.

Group $\mathrm{T} 2$ and $\mathrm{T} 3$ were the best in maintaining viability. There was no difference ( $\mathrm{p}>0.05$ ) between group T2 and T3, but both groups were significantly different $(\mathrm{p}<0.05)$

Table 2 Spermatozoa viability (\%, means \pm SD) after cooling in skim milk egg yolk diluent with $\alpha$ tocopherol supplementation

from $\mathrm{T} 0$ and $\mathrm{T} 1$ throughout the observation time (Table 1.2). Significant differences in viability have been found 24 hours after cooling.

\begin{tabular}{lcccc}
\hline & \multicolumn{4}{c}{ time of observation after cooling (hours) } \\
\cline { 2 - 5 } & 0 & 24 & 48 & 72 \\
\hline T0 & $93.1 \pm 2.7^{\mathrm{a}}$ & $75.1 \pm 4.3^{\mathrm{a}}$ & $53.5 \pm 4.6^{\mathrm{a}}$ & $32.9 \pm 3.6^{\mathrm{a}}$ \\
T1 & $92.8 \pm 1.8^{\mathrm{a}}$ & $81.9 \pm 4.0^{\mathrm{b}}$ & $63.7 \pm 5.4^{\mathrm{b}}$ & $39.3 \pm 1.4^{\mathrm{a}}$ \\
T2 & $93.5 \pm 1.8^{\mathrm{a}}$ & $88.3 \pm 2.9^{\mathrm{c}}$ & $82.3 \pm 2.4^{\mathrm{c}}$ & $58.8 \pm 7.5^{\mathrm{b}}$ \\
T3 & $93.1 \pm 1.9^{\mathrm{a}}$ & $90.5 \pm 2.7^{\mathrm{c}}$ & $84.3 \pm 1.9^{\mathrm{c}}$ & $65.9 \pm 7.2^{\mathrm{b}}$ \\
\hline
\end{tabular}

a, b, c different superscripts in the same column indicates significant difference ( $p<0.05)$; T0: control, without supplementation; T1: supplementation with $0.5 \mathrm{mM} \alpha$-tocopherol; T2: supplementation with $1.0 \mathrm{mM} \alpha$-tocopherol; T3: supplementation with $1.5 \mathrm{mM} \alpha$-tocopherol; replicates: 5 (ejaculates); cooling was conducted at $5{ }^{\circ} \mathrm{C}$. 
Evaluation of plasma membrane integrity showed the highest maintenance of plasma membrane integrity occurred in group T3 (Table 1.3). Observation at 48 as well as 72 hours after cooling in plasma membrane integrity showed a significant difference $(\mathrm{p}<0.05)$ between T3 and the other groups.

Table 3 Spermatozoa plasma membrane integrity (\%, means \pm SD) after cooling in skim milk egg yolk diluent with $\alpha$-tocopherol supplementation

\begin{tabular}{lcccc}
\hline & \multicolumn{4}{c}{ time of observation after cooling (hours) } \\
\cline { 2 - 5 } & 0 & 24 & 48 & 72 \\
\hline T0 & $63.84 \pm 7.9^{\mathrm{a}}$ & $43.97 \pm 8.7^{\mathrm{a}}$ & $20.52 \pm 6.1^{\mathrm{a}}$ & $8.90 \pm 2.6^{\mathrm{a}}$ \\
T1 & $62.18 \pm 5.7^{\mathrm{a}}$ & $51.03 \pm 7.9^{\mathrm{ab}}$ & $30.15 \pm 4.7^{\mathrm{b}}$ & $11.90 \pm 1.5^{\mathrm{a}}$ \\
T2 & $62.47 \pm 6.3^{\mathrm{a}}$ & $54.58 \pm 9.3^{\mathrm{ab}}$ & $31.59 \pm 4.3^{\mathrm{b}}$ & $18.27 \pm 2.7^{\mathrm{b}}$ \\
T3 & $63.77 \pm 6.1^{\mathrm{a}}$ & $58.53 \pm 6.2^{\mathrm{b}}$ & $48.48 \pm 5.8^{\mathrm{c}}$ & $27.95 \pm 4.1^{\mathrm{c}}$ \\
\hline
\end{tabular}

$\mathrm{a}, \mathrm{b}, \mathrm{c}$ different superscripts in the same column indicates significant difference $(\mathrm{p}<0.05)$; T0: control, without supplementation; T1: supplementation with $0.5 \mathrm{mM} \alpha$-tocopherol; T2: supplementation with $1.0 \mathrm{mM} \alpha$-tocopherol; T3: supplementation with $1.5 \mathrm{mM} \alpha$-tocopherol; replicates: 5 (ejaculates); cooling was conducted at $5{ }^{\circ} \mathrm{C}$.

\section{DISCUSSION}

The cooling process decreased membrane fluidity, spermatozoa motility, and velocity (Chatterjee and Gagnon, 2001). Spermatozoa membrane has a high percentage of poly unsaturated fatty acids (PUFAs). Reactive oxygen species was produced by a variety of semen components, including immotile or morphologically abnormal spermatozoa, leucocytes and morphologically normal but functionally abnormal spermatozoa. Oxidative stress (OS) has been recognized as one of the most important causes of infertility, despite the antioxidant activity of seminal plasma, epididymis, and spermatozoa, OS damaged spermatozoa function and DNA integrity. Although necessary for survival, oxygen also led to the production of free radicals. These are atomic or molecular species with unpaired electrons on an otherwise open shell configuration. Unpaired electrons were usually highly reactive, so radicals were likely to take part in chemical reactions that damage spermatozoa plasma membrane lipids (called lipid peroxidation) (Jones and Mann, 1977). Lipid peroxidation of the spermatozoa membrane was responsible for causing perturbation of membrane structure and function (transport processes, maintenance of ion and metabolite gradient, receptor-mediated signal transduction) (Sikka,1996). The injury caused not only the loss of membrane integrity but also increased membrane permeability. The increase in membrane permeability was suggested to give a deleterious effect on intracellular concentration regulator for ions involved in controlling the spermatozoa movement (Kumar et al., 2011). Therefore, the damage of the membrane structure reduced spermatozoa overall functions.

Mammalian spermatozoa were highly susceptible to the reactive oxygen species (ROS) stress caused by biochemical and physical modifications during the cryopreservation process as cooling process caused a sudden outburst of ROS generation (Chatterjee and Gagnon, 2001). Antioxidants such as $\alpha$-tocopherol helped clear the ROS produced by the electron transport chain in the mitochondria from creating a chain reaction in the cell membrane. Alpha-tocopherol inhibited the stage of lipid peroxidation propagation through the transfer of $\mathrm{H}$ atoms. The reaction resuled $\alpha$-tocopherol radical and non-radical products . After the formation of $\alpha$-tocopherol radicals, they immediately reacted with the second free radical or each other to form a non-radical end product.

In this study, the best results were found in 
diluted semen supplemented with $1.5 \mathrm{mM} \alpha-$ tocopherol. However, some studies did not show the same effect of the same dose in this study. $1.5 \mathrm{mM}$ evaluation displayed an adverse effect in plasma membrane integrity maintenance (Tafif, 2019) that analogues of vitamin $E$ had negative effects when it was added to the refrigerated medium of ram (Mata-Campuzano et al., 2014) and red deer (Anel-López et al., 2012) spermatozoa. This discrepancy might be related to the efficiency of antioxidants, which were affected by various factors such as the component of buffer, cryoprotectants, and incubation time.

Cryoprotectants such as egg yolk and soybean or milk have different antioxidant capacity (Alvarez-Rodríguez et al., 2013) either way; the results of previous studies corresponded with the result of the present study. The supplementation $\alpha$-tocopherol in egg yolk tris aminomethane diluent resulted in beneficial effect on spermatozoa motility and plasma membrane integrity in Madura bull (Ratnani et al., 2017). A lso $\alpha$-tocopherol can be an efficient antioxidant additive in Bioxcell extender for cryopreservation of bull semen (Motemani et al., 2017).

\section{CONCLUSION}

Supplementation of $\alpha$-tocopherol at $1.5 \mathrm{mM}$ in skim milk egg yolk diluent maintained Simmental bull spermatozoa motility, viability, and plasma membrane integrity during cooling at $5^{\circ} \mathrm{C}$ whereas, at $1.0 \mathrm{mM}$ only spermatozoa viability were maintained.

\section{REFERENCES}

Agarwal A, Saleh RA, Bedaiwy MA. 2003. Role of reactive oxygen species in the pathophysiology of human reproduction. Fertil Steril. 79: 829-43.

Alvarez-Rodríguez M, Alvarez M, Anel-López L, Martínez-Rodríguez C, Martínez-Pastor F, Borragan S, Anel L, de Paz P. 2013. The antioxidant effects of soybean lecithin- or low-density lipoprotein-based extenders for the cryopreservation of brown-bear (Ursus arctos) spermatozoa. Reprod Fertil Dev. 25: 1185-93.
Anel-López L, Alvarez-Rodríguez M, GarcíaÁlvarez O, Alvarez M, Maroto-Morales A, Anel L, de Paz P, Garde JJ, MartínezPastor F. 2012. Reduced glutathione and Trolox (vitamin E) as extender supplements in cryopreservation of red deer epididymal spermatozoa. Anim Reprod Sci. 135: 37-46.

Bebas W, Gorda W. 2016. Penambahan Astaxanthin pada Pengencer Kuning Telur Berbagai Jenis Unggas Dapat Memproteksi Semen Babi Selama Penyimpanan. Jurnal Veteriner 17: 484-91.

Chatterjee S, Gagnon C. 2001. Production of reactive oxygen species by spermatozoa undergoing cooling, freezing, and thawing. Mol Reprod Dev. 59: 451-8.

Hariyatmi. 2004. Kemampuan Vitamin E sebagai Antioksidan terhadap Radikal Bebas pada Lanjut Usia. Jurnal MIPA. Universitas Muhammadiyah Surakarta Jurnal MIPA 14: 52-60.

Jackson MJ. 2005. Reactive oxygen species and redox-regulation of skeletal muscle adaptations to exercise. Philos Trans R Soc Lond B Biol Sci. 360: 2285-91.

Jones R, Mann T. 1977. Toxicity of exogenous fatty acid peroxides towards spermatozoa. $\mathrm{J}$ Reprod Fertil. 50: 255-60.

Kumar R, Jagan Mohanarao G, Arvind, Atreja SK. 2011. Freeze-thaw induced genotoxicity in buffalo (Bubalus bubalis) spermatozoa in relation to total antioxidant status. Mol Biol Rep. 38:1499-506.

Kusumaningrum DA, Situmorang P, Setioko AR, Sugiarti T, Triwulanningsih E, Sianturi RG. Pengaruh Jenis dan Aras Krioprotektan Terhadap Daya Hidup Spermatozoa Entog. J Ilmu Ternak dan Vet. 7: 244-50.

Mata-Campuzano M, Álvarez-Rodríguez M, Tamayo-Canul J, López-Urueña E, de Paz P, Anel L, Martínez-Pastor F, Álvarez M. 2014. Refrigerated storage of ram sperm in presence of Trolox and GSH antioxidants: effect of temperature, extender and storage time. Anim Reprod Sci. 151: 137-47.

Motemani M, Chamani M, Sharafi M, Masoudi R. 2017. Alpha-tocopherol improves frozen-thawed sperm quality by reducing 
hydrogen peroxide during cryopreservation of bull semen. Spanish J Agric Res. 15: 1-7

Priyanto L, Arifiantini RI, Yusuf TL. 2015. Deteksi kerusakan DNA spermatozoa semen segar dan semen beku sapi menggunakan pewarnaan toluidine blue. $\mathbf{J}$ Veteriner 16: 48-55.

Ratnani H, Ihsan MN, Ciptadi G, Suyadi S. 2017. Effect of $\alpha$-Tocopherol supplementation in the extender on the sperm quality of Maduran bull before and after quick freezing. Int $\mathrm{J}$ Adv Res. 5: 1378-89.

Sikka SC. 1996. Oxidative stress and role of antioxidants in normal and abnormal sperm function. Front Biosci. 1: e78-86.

Singh VS. 1992. A current perspective on nutrition and exercise. J Nutr. 122: 760-65.

Soeharsono, Saptati RA, Diwyanto K. 2010. Penggemukan sapi lokal hasil Inseminasi Buatan dan sapi bakalan impor dengan menggunakan bahan pakan lokal. Seminar Nasional Teknologi Peternakan dan Veteriner. Badan Litbang Pertanian. Kementrian Pertanian-Republik Indonesia. Bogor.
Suryohudoyo P. 1995. Oksidan, antioksidan dan radikal bebas. Dalam: Makalah dalam Kongres Nasional IV Himpunan Kimia Klinik Indonesia. Surabaya.

Susilowati S, Hardijanto, Suprayogi TW, Sardjito T, Hernawati T. 2010. Penuntun Praktikum Inseminasi Buatan. $1^{\text {st }}$ Ed. Airlangga University Press. Surabaya.

Tafif K. 2019. The effect of alpha-Tocopherol supplementation in skim milk diluent of Sapudi ram on spermatozoa motility, viability, plasma membrane integrity, and chromatin damage [Thesis]. Faculty of Veterinary Medicine. Universitas Airlangga. Surabaya.

Tremellen K. 2008. Oxidative stress and male infertility-a clinical perspective. Hum Reprod Update 14: 243-58. 